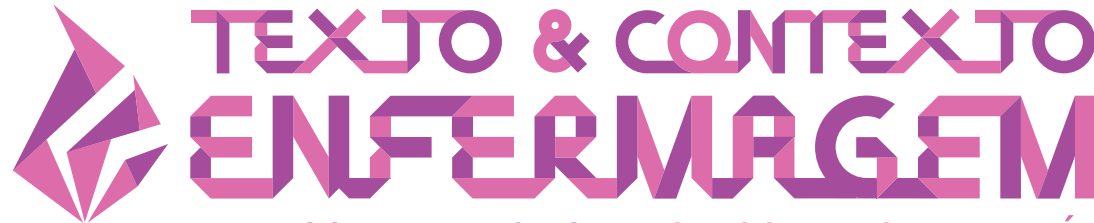

\section{PROFESSORS' PERCEPTION OF MENTAL HEALTH TEACHING IN NURSING}

\author{
Jeferson Rodrigues ${ }^{1}$ \\ Daniele Delacanal Lazzari' \\ Jussara Gue Martini ${ }^{1}$ (C) \\ Ana Karoliny Testoni ${ }^{1}$ (iD
}

${ }^{1}$ Universidade Federal de Santa Catarina, Departamento de Enfermagem. Florianópolis, Santa Catarina, Brasil.

\begin{abstract}
Objective: to understand how mental health education is developed in a nursing undergraduate course based on professors' perceptions of specific disciplines.

Method: qualitative, exploratory and descriptive research, developed with 11 nursing professors of mental health disciplines, from a public university in the south of Brazil. Data collection was performed through semistructured interview in 2014. Data were submitted to thematic analysis.

Results: the following categories emerged: Training for mental health education; Specificities of teaching in mental health; and Development of practical classes / internships in mental health. Mental Health education, which prioritizes cognitive and technical aspects in line with the Psychiatric Reform, the consolidation of the Unified Health System and the implementation of the National Nursing Curricular Guidelines, becomes a challenge as the break with the teaching model and health, once in force, is current.

Conclusion: this scenario highlights the need for mental health education training for nursing professors and ongoing curricular revision and pedagogical strategies.
\end{abstract}

DESCRIPTORS: Mental health. Teaching. Nursing. Faculty, nursing. Nursing education. 


\section{ENSINO DA SAÚDE MENTAL EM ENFERMAGEM NA PERCEPÇÃO DE PROFESSORES}

\section{RESUMO}

Objetivo: compreender como se desenvolve o ensino de saúde mental em um curso de graduação em enfermagem a partir da percepção dos professores de disciplinas específicas.

Método: pesquisa qualitativa, exploratória e descritiva, desenvolvida com 11 professores de enfermagem de disciplinas relativas à saúde mental, de uma universidade pública do sul do Brasil. Coleta de dados realizada, por entrevista semiestruturada em 2014. Os dados foram submetidos à analise temática.

Resultados: emergiram as seguintes categorias: Formação para o ensino da saúde mental; Especificidades do ensino na saúde mental; e Desenvolvimento de aulas práticas/estágios em saúde mental. O ensino em Saúde Mental, que prioriza aspectos cognitivos e técnicos em consonância à Reforma Psiquiátrica, à consolidação do Sistema Único de Saúde e à implantação das Diretrizes Curriculares Nacionais de Enfermagem, torna-se um desafio à medida em que a ruptura com modelo de ensino e saúde, outrora vigente, segue atual.

Conclusão: este cenário aponta para a necessidade de formação de professores enfermeiros para o ensino de saúde mental e permanente revisão curricular e das estratégias pedagógicas.

DESCRITORES: Saúde mental. Ensino. Enfermagem. Docentes de enfermagem. Educação em enfermagem.

\section{ENSEÑANZA DE LA SALUD MENTAL EN ENFERMERÍA EN LA PERCEPCIÓN DE PROFESORES}

\section{RESUMEN}

Objetivo: comprender cómo se desarrolla la enseñanza de salud mental en un curso de graduación en enfermería a partir de la percepción de los profesores de disciplinas específicas.

Método: investigación cualitativa, exploratoria y descriptiva, desarrollada con 11 profesores de enfermería de disciplinas relativas a la salud mental, de una universidad pública del sur de Brasil. Recolección de datos realizada, por entrevista semiestructurada en 2014. Los datos fueron sometidos al análisis temático.

Resultados: surgieron las siguientes categorías: Formación para la enseñanza de la salud mental; Especificidades de la enseñanza en la salud mental; y Desarrollo de clases prácticas / pasantías en salud mental. La enseñanza en Salud Mental, que prioriza aspectos cognitivos y técnicos en consonancia a la Reforma Psiquiátrica, a la consolidación del Sistema Único de Salud ya la implantación de las Directrices Curriculares Nacionales de Enfermería, se vuelve un desafío a medida en que la ruptura con modelo de enseñanza y la salud, otrora vigente, sigue presente.

Conclusión: este escenario apunta a la necesidad de formación de profesores enfermeros para la enseñanza de salud mental y permanente revisión curricular y de las estrategias pedagógicas.

DESCRIPTORES: Salud mental. Educación. Enfermería. Docentes de enfermería. Educación en enfermería. 


\section{INTRODUCTION}

The teaching of care to the person with a mental disorder is offered to the undergraduate nursing students in courses, commonly called, Nursing in Mental and / or Psychiatric Health. The purpose of these courses is to teach the skills and competences, found in the principles of the Psychiatric Reform, which include sensitivity and empathy, with particular focus on the understanding and development of a therapeutic relationship, as well as the constant exercise of perceiving oneself in the nurse / patient relationship".

The need to break with educational paradigms has occurred not only due to the Psychiatric Reform itself, but also due to changes in the curriculum of the undergraduate nursing courses, proposed by the National Curricular Guidelines for Nursing (Diretrizes Curriculares Nacionais do Curso de Graduação em Enfermagem - DCNEnf) established in 2001.2

Although educational reforms have redirected the production of flexible curricula and are understanding to regional priorities and health context particularities, there are still limitations in academic mental health training, such as reduced workload, lack of further discussions and the instrumentalization of the university in teaching, resulting in the poor development of skills and competences directed to this type of care. Furthermore, the focus of health practices on disease, reinforcing the biological approach, which favors drug treatments, maintaining fragmented training, unrelated to the principles of comprehensive care of health professionals. ${ }^{3}$

The development of certain competences, skills and critical and reflective training revealed the need for teaching practices that allowed or stimulated other training perspectives, adapted to the needs of the community and which were associated with the development of criticality and action / reflection. ${ }^{2}$

In this context, clinical training has become fundamental for student learning as it allows learning in the complex spaces of Mental Health practice. ${ }^{4}$ For this reason, in the universe of curricular reformulations which concerns teaching and content strategies, the teacher preparation of professors for such actions is urgently required.

Understanding the training of professors is also a priority. To think how, in the midst of such changes, teaching has acquired new profiles, adapting or failing to adapt itself to what is planned by institutionalized policies and guidelines, also refers to the egress profile intended in contemporary times.

The content and the strategies used by professors are influenced by their own training process, almost always removed from pedagogical references and closer to affective memories related to the performance of their former professors and plans based on hits and misses. The intentionality of modifying plans or defining topics in the sense of teaching specialty within a generalist approach are significant steps in the teaching process. The promotion of diverse learning practices is based on the conception of mental health that the professor possesses, how critical / political his / her view on the specialty is and is an effective pedagogical tool for the transformation of the work processes in mental health.

Understanding the perceptions of those who are directly involved in the formal structuring of mental health disciplines reveals the interest and personal motivations of professors in the care setting, in the classroom, in the problematization of the suffering individual, and in the comprehensive clinical evaluation. ${ }^{5}$

The changes brought the rhetorical necessity to decentralize the image of the professor as the center of the teaching process, although one can effectively perceive, through the absence of pedagogical training, the profound separation between those who decide under the control of scientificity and the students. ${ }^{6}$ Therefore, it is not only to train professors technically for pedagogical practice but to establish them as agents that promote change, both in the acceptance of innovative 
positions, and in the commitment to the adoption of pedagogical theoretical references that allow a true transformation of the professional development, based on the offer of meaningful learning. ${ }^{4}$

Therefore, understanding the professor as a manager of pedagogical changes, and observing that in recent decades the question of teacher training and the teaching profession has been the center of educational reform proposals, this research was based on the following guiding question: what are the perceptions of professors regarding their participation in the development of mental health teaching in undergraduate nursing training? The objective was to understand how mental health education is developed in an undergraduate nursing course based on the professors' perception of the specific disciplines.

\section{METHOD}

A qualitative study, with a descriptive exploratory approach. A semi-structured interview was used as the data collection strategy. The participant selection occurred by inviting all professors who taught mental health / psychiatric disciplines from 1969 to 2014 in an undergraduate nursing degree course at a public university in the southern region of Brazil.

The adopted inclusion criteria were: to be a retired or an employed professor of the university, and to have taught the Psychiatric Nursing discipline or mental health content in other disciplines (identified through the teaching plans).

The data were collected for four months (July to September 2014). The interviews were previously scheduled and adapted to the availability of each participant, and were performed in a reserved environment in order to maintain privacy and individually. The interviews lasted between 40 to 120 minutes and were recorded and saved on a digital file.

The Pedagogical Projects of the Graduation Course were consulted over the years, as well as the Teaching Plans of the mental health disciplines. The names of the teachers who taught classes in this curricular component were selected from the latter.

The aim of the interviews was to identify the teaching of theoretical and theoretical-practical nursing according to the perceptions of the professors. A script was used in the semi-structured interview and it was aimed to understand the experience, the relationships that they developed with the pedagogical process, the specific area of knowledge and the challenges of the time.

The data were analyzed qualitatively using Thematic Analysis ${ }^{7}$ finding core meanings, composed of three stages: pre-analysis, material exploration, treatment of obtained results and interpretation.

Individuals who agreed to participate in the study signed an Informed Consent Form. Interviewees were identified by alphanumeric code in the order of interviews and by the letter $P$ for Professor.

\section{RESULTS}

The findings from the data analysis allowed us to elaborate the following categories of results: Training for mental health education; Specificities of teaching in mental health; and, Practices / Internships in mental health.

\section{Training for mental health education}

Through the current training proposals, structured after the curricular reforms after or before the DCNEnf, and the Mental Health Policy of the Unified Health System, the training itinerary of teachers or the perception they have of their own training make up an important part of the teaching in the area. There is no itinerary of clinical training among the teachers participating in this study, either those who had already retired or those currently working. This was due to arising opportunities or personal interest in the area in order to achieve rapprochement with the discipline. 
When I started university, I was immediately asked what area I would like to do. I always wanted to work with mental health, it was what I liked, but I would have had to wait for a place, so I worked in other areas. Then, a teacher retired and they called me to work in mental health, in psychiatric nursing (P1).

The head of the department at the time invited me to go to psychiatry. I went, there were 4 teachers at the time. And I stayed in psychiatry until my retirement (P2).

Training at the masters or doctoral or internship levels was established as a way of approaching the area and strengthening the specialty.

I did an internship in Ribeirão Preto (Brazil) with a teacher who was the national reference for psychiatric nursing. I went back and went with a psychiatric nursing teacher until he thought I was fit. For me, this internship was excellent, it gave me an advantage, do you understand? (P3).

I did a master's degree in Psychiatric Nursing at USP [Universidade de São Paulo) and my dissertation involved psychiatry and law (P4).

It was also noticed that for some professors associating mental health with other specialties or perceiving them within a broader general context, associated with other teaching activities in nursing was the beginning of their journeys within the Mental Health / Psychiatric Nursing discipline.

I had done a specialization in pediatric nursing and worked for 18 years as a pediatric nursing professor. However, I did a research project on therapeutic touch and I thought: why doesn't nursing use the therapeutic touch as a methodology? (P5).

I really wanted to work with the mental health aspects in the elderly, I saw that there were many in daily care and that we did not approach this in the course. I made a proposal, I looked for the teachers, I showed my interest. After, a position opened up due to a retirement and she came to me (P6).

The interest of each professor to act in the discipline related to Mental Health was constituted from the individual desire of each one, even in the absence of clinical training in the area, such as psychoanalytic training.

\section{Specificities of mental health education}

When questioned about the specificities of Mental Health teaching, the professors highlighted tasks that they envisioned differentiated approaches for students in an attempt to connect with the suffering individual. The difficulties of starting in a discipline previously developed by other professors or not being part of the organization process of the discipline was also present

I did not see the logic of the content. And I think that in each phase of the course, one can approach certain disorders, legislation, therapeutic communication, psychiatric work, but without a logic of where it begins and ends. I did not see the approach of this logic to train the student to understand this context of care, and we needed this context of care, to know how he cared in other times, how he cares today (P7).

The content approach evidenced the attempt to comprehend the theme and modify the focus of the disease specifically through theoretical references. The perception that the work with the student was beyond the teaching of content and should be include its transformation as a subject that takes responsibility for care and was also present.

With regard to the content, first the History of Psychiatry, Theories of Basic Human Needs of Wanda Aguiar Horta, the difference between neurosis and psychosis, legal aspects of care and the mentally ill, etc. were approached first. We did not study mental illnesses or psychiatric conditions; our concern was to give a nursing view of care and attention to basic human needs (P4). 
We worked a lot on Joyce Travelbee, interpersonal relationship and in the end we had to work with the student for a while, because they were afraid of facing the patient. And then when we realized, many students already told the patient 'I'll take care of you' (P1).

There is something that bothers me and we have discussed a lot today ... At what point did we say that physical health was one thing and mental health was another? I have reassembled the concept of health with the students because we need to look at it (P7).

Regarding didactic approaches, changes in the evaluation pattern and behavior of professors regarding this aspect of teaching are innovative, but bring with them the concern that the subjectivity of this choice influences the processes.

We did not have proof. We chose more for a daily follow-up of a group of four or five students, it was like an internship. We formed a concept, it was very nice, maybe it was even very subjective, but the important thing was that we considered the individual (P8).

It was important to understand that the subject with limitations can do things. What can I work on? What type of insertion can this individual have with this type of limitation? (P3).

The specificity of teaching in mental health is also a concern, since the absence of pedagogical training added to the absence of clinical training in mental health implies nuances in the way of teaching. Concerns about student evaluation and excessive subjectivity coexist with the perception of the comprehensiveness of care and constitution of the subjects, considering them in their individuality and consequently allowing genuine expressions of teaching, considering who is the subject who learns.

\section{Practices / Internships in Mental Health}

The internships in mental health are places of attention that give teachers and students the possibility to construct nursing practices on a daily basis, through contradictions and confrontations related to nursing and its teaching, in an attempt to consider the other (patient) as a social subject.

What we prevailed was that whatever action the student takes, he should take into account the mental health of the person. If it was a dressing, it is important to see how the person is, look at their mental health. The patient came here because of a physical issue, or even if he had some mental health issue or disorder that was being treated in the unit, we take the opportunity to work on these issues a little more (P7).

It is important for the student to recognize, to live a little with patients with mental disorders, with the mad person, at the time we had no problem in calling them mad. And be able to identify forms of expression of this suffering, this madness. We worked on the most dangerous cases of madness, including those who committed acts against themselves and against others (P1).

The didactic organization of the practices / internship, while allowing the teacher to give specific attention to smaller groups of students, reproduced the fragmentation of care and the complete nonaccompaniment of the teacher even through smaller groups and the change in the curriculum.

At first, I went with six students and it was difficult. I stayed with one or two and distributed the others in the unit. There, some could see one thing, others could see another. I felt it was more difficult in the old curriculum, because in the new curriculum it seems that this has been clarified because mental health and primary care are in the same year, but they are different things, at least we managed to set that straight (P2).

Each teacher had a group of students under his or her responsibility, the focus was on an adapted theory of basic human needs (P8).

In the practice of care, the relationship with psychiatrists represented a barrier that no longer existed in the relationship with technicians, assistants and attendants. The practices of exposing bodies and annihilation of individuality were observed by the students in the same space in which it was intended to fully understand the other. 
Students observed what medication the patients were taking, and it was very difficult to relate to psychiatrists in this regard. They participated in the basic care such as bathing with technicians, assistants and attendants. Bathing was done on the patio, and we worked on the issue of self-image, the absence of privacy. There were many patients and few employees, but there was no privacy for the patient (P6).

We started with a visit, history, the students were divided into groups by the teachers, and they tried to do an intervention. The student did not have access to the chart at first, as it was hoped that the student would exercise therapeutic communication, the person-to-person relationship, with a randomly chosen hospitalized patient. We wanted the student to understand the human being, rather than the disorder he had (P4).

There was concern on the part of teachers to recognize the need to improve mental health education, and even the desire to establish a new order within the care system. However, living with the patient treated as a non-citizen, left deep marks on everyone involved, from students and teachers to the professionals themselves.

\section{DISCUSSION}

In order for the development of a pedagogical practice that considers the other in its totality and fosters the development of a social subject, attentive to the demands of his time, nursing professors face, the absence of specific teaching training, the obligation to adapt to the new times and the challenge of understanding the impositions of liberal policies that make the professor a practitioner who teaches.

In addition to this, there is a need to train professionals who can continue to reinforce the Psychiatric Reform and its service network in out-of-hospital spaces, aimed at psychosocial rehabilitation, by welcoming and respecting patients. ${ }^{8}$ In this way, professors are encouraged to understand who is the subject who teaches mental health and to what extent their pedagogic or specialized training or absence of these compose the teaching in the area. Due to the specificities, sensitive treatment with patients, established policies, the connection with the other in a society that privileges the normal to the detriment of everything that is not, being a mental health professor may, under a certain perspective, require clinical training, even in the absence of pedagogical training.

How then do we train professionals who can identify the influencers of the state of equilibrium of the human being, develop empathy, therapeutic relationship and constant exercise of self-knowledge? ${ }^{1}$ In this setting, it is understood that the clinical training for working in mental health teaching can assist in the training of professors firmly focused on psychiatry models with critical approaches to reality, in the context of new services, removed from the old references once adopted, without reinforcing knowledge and practices of exclusion of madness. ${ }^{9}$

The mental health discipline enables students to make the first formal contact with patients with mental disorders, awakening fantasies and concerns regarding the behavior of these patients and about what is mad. The preparation of the professor who works in this discipline can foster the re-signification of the nurses' work, deconstructing stereotyped views about the health / illness process, as well as discouraging the individual's classification into diagnostic categories. ${ }^{10}$

The training itineraries of the participants of this study highlight the absence of specialized training and teaching in the area guided by personal desires, without formal concern with pedagogical or clinical training, even in the face of the changes that define how mental health and its teaching are perceived today.

Reorienting mental health teaching as a tool to modify work processes in the area involves the experience of students and professors in different places of mental health care and should provide 
conditions for the development of skills and abilities within and outside the scope outlined by DCN, including training for professional practice, regardless of being generalist. ${ }^{2,11}$

However, difficulties are still encountered with regard to theory and practice in mental health care, including the qualification of practice professionals and professors through the still present remnants of asylum policies, even in the face of the increase and strengthening of the out-of-hospital network system. ${ }^{2,12}$ Therefore, it is understood that the particularities of care in the Psychosocial Care Centers (CAPS) require the revision of teaching practices in order to sustain the academic training and the experiences in the internships. ${ }^{13-14}$

In general, difficulties and pedagogical obstacles influence teaching activity. The understanding that teacher training in practice or based on past experiences, action-reflection-action or even through sporadic training courses opposes the need for training that encourages professors to theorize their teaching practice. The management of student learning, activity planning and the use of pedagogical strategies appropriate to the teaching learning process in different contexts still present difficulties.

The selection of content and its organization in the curriculum are also challenges. The traditional curricular structure, divided into disciplines and cycles, with prevalence of the biomedical model and consequent emphasis on hospital practices, is typical of teaching in the area of health in general. With the institution of the DCN and the new perceptions regarding the learning and teaching processes, the use of differentiated methodologies and the selection of content are possibilities that allow to rethink teaching and analyze the need of pedagogical training for nursing professors, and consequently, mental health in nursing ${ }^{15-16}$

The disagreement highlighted by the participants of this study between the practice of mental health at the time and the pedagogical practice evidences the difficulty of acting in scenarios that reinforced the exclusion and the stereotypes related to madness. The teaching and learning experiences and the difficulties students face in these spaces can be minimized by the multiple strategies available today, including the scope of simulated teaching, providing previous experiences of the fields of practice / internships. The less traditional methodologies adopted for student evaluation are also important pedagogical resources to be used in an attempt to approach them and make learning a meaningful experience. ${ }^{16}$

The use of mental health content is used to instrumentalize students in the development of relational, communication and attitudinal skills, reinforcing the importance of mental health in the curricula of undergraduate nursing courses. ${ }^{17}$ Providing pedagogical practices consistent with the Mental health policies remains a challenge. It is in this context that the absence of pedagogical and clinical training imposes new demands: the permanence of the pedagogical conceptions acquired throughout life, values, beliefs and customs require changes in a constructed educational system. ${ }^{18}$

There is a lack of professionals or insufficient preparation of nursing professors who work in the disciplines related to mental health to deal with patients suffering from psychiatric issues, and this understanding is necessary to support models of practice and pedagogical choices, inserted in the new psychosocial paradigm that proposes the training of nurses through socio-cultural precepts in accordance with the principles of the Brazilian Unified Health System. ${ }^{19}$ Nursing courses are intended to promote practices that favor the holistic perception of the human being and the non-fragmentation of the individual by the disease. ${ }^{20}$

The limitation of the study reveals a researched reality that does not consider generalization, considering that each teaching scenario has its own specificities, periods in history and constituents that involve the teaching institution. 


\section{CONCLUSION}

The teaching of nursing in mental health has undergone profound changes in its practices, prioritizing cognitive and technical aspects. The implementation of the Psychiatric Reform, the consolidation of the Unified Health System and the establishment of the National Nursing Curricular Guidelines allowed and continues to foster a break with a teaching and health model that was once in force. The distances between teaching and practice in mental health highlight the need for teacher training for nurses, permanent curricular revision and pedagogical strategies.

The relationship between pedagogical training and clinical approach in the field of mental health requires cautious choice, since there are several theoretical methodological references that integrate these two areas. One of the limits is the coherence of a pedagogical reference with the clinician, inserted in an ideological and contextual structure, like a Freirean pedagogical training (Paulo Freire) with the endorsement of Joyce Travelbee (Logoterapia - Viktor Frankl). Thus, research analyzing this relationship is necessary for the rigor of teaching a field where one commonly hears that "anything goes". Likewise, evaluation research on tprofessor education in mental health education in the perspective of general education is also necessary.

Teaching praxis in mental health needs to reflect the social, economic, and political determinants that interfere with being a professor and that also represents the interests of its institution. This reflection demands a critical position that requires political engagement in associative bodies in order to rethink the situation of mental health teaching in Brazilian undergraduate nursing courses in Brazil.

\section{REFERENCES}

1. Rodrigues J, Santos SMA, Zeferino MT, Tosoli M. Integrative review about the teaching of the nursing care in mental health. Rev Pesqui Cuid Fundam [Internet]. 2014 [cited 2016 Dec 10];6(1):433-49. Available from: http://www.seer.unirio.br/index.php/cuidadofundamental/article/ view/2650/pdf_1109

2. Villela JC, Maftum MA, Paes MR. The teaching of mental health in a nursing undergraduate course: a case study. Texto Contexto Enferm [Internet]. 2013 [cited 2016 Nov 15];22(2):397-406. Available from: http://www.scielo.br/pdf/tce/v22n2/en_v22n2a16.pdf

3. Pessoa Júnior JM, Santos RCA, Clementino FS, Nascimento EGC, Miranda FAN. Mental health education and professional practice in the psychiatric hospital. Texto Contexto Enferm [Internet]. 2016 [cited 2016 Nov 15];25(3):e3020015. Available from: https://dx.doi.org/10.1590/010407072016003020015

4. Silva R, Pires R, Vilela C. Supervisão de estudantes de enfermagem em ensino clínico: revisão sistemática da literatura. Rev Referência [Internet]. 2011 [cited 2016 Nov 20];3(3):113-22. Available from: http://www.scielo.mec.pt/pdf/ref/vserllln3/serllln3a12.pdf

5. Rodrigues J, SMA Santos, Spricigo JS. Teaching mental health nursing care through the faculty's discourse. Texto Contexto Enferm [Internet]. 2012 [cited 2016 Nov 15];21(3):616-24. Available from: http://www.scielo.br/pdf/tce/v21n3/en_v21n3a17.pdf

6. Pardal L, Neto-Mendes A, Martins A, Gonçalves M, Pedro A. Quando for grande vou ser professor: a identidade docente representada por futuros professores. Rev Diálogo Educ [Internet]. 2011 [cited 2016 Nov 15];11(33):417-33. Available from: https://ria.ua.pt/bitstream/10773/6978/1/ identidade\%20docente\%20Repres.pdf

7. Minayo MCS. O desafio do conhecimento: pesquisa qualitativa em saúde. São Paulo(BR): Hucitec;2007. 
8. Calgaro A, Souza EN. Percepção do enfermeiro acerca da prática assistencial nos serviços públicos extra-hospitalares de saúde mental. Rev Gaúcha Enferm [Internet]. 2009 [cited 2016 Nov 15];30(3):476-83. Available from: http://seer.ufrgs.br/index.php/RevistaGauchadeEnfermagem/ article/view/6490/6968

9. Pereira RFR, Freitas ALA, Prado SO, Gomes ALS, Marilac AF, Sousa JI, et al. Construindo saberes no trabalho em saúde mental: experiências de formação em saúde. Interface Comum Saúde Educ [Internet]. 2015 [cited 2016 Nov 10];19(1):931-40. Available from: http://www.scielo. br/pdf/icse/v19s1/1807-5762-icse-19-s1-0931.pdf

10. Tardivo LC, Salle RJ, Gabriel Filho L. Uma proposta de formação do psicólogo em saúde mental Ensino, pesquisa e intervenção. Educ Soc Cult [Internet]. 2013 [cited 2016 Nov 15];39:79-99. Available from: http://www.fpce.up.pt/ciie/sites/default/files/06.LeilaTardivo_etal.pdf

11. Soares AN, Silveira BV, Reinaldo AMS. Serviços de saúde mental e sua relação com a formação do enfermeiro. Rev Rene [Internet]. 2010 [cited 2016 Dec 10];11(3):47-56. Available from: http:// www.revistarene.ufc.br/vol11n3_pdf/a05v11n3.pdf

12. Barros S, Claro HG. The teaching-learning process in mental health: the student's perspective about psychosocial rehabilitation and citizenship. Rev Esc Enferm USP [Internet]. 2011 [cited 2016 Dec 10];45(3):700-7. Available from: http://www.scielo.br/pdf/reeusp/v45n3/en_v45n3a22.pdf

13. Silva GM, Beck CLC, Figueiredo ACC, Prestes FC. O processo de trabalho na supervisão clínico-institucional nos Centros de Atenção Psicossocial (CAPS). Rev Latino-Am Psicopatol Fundam [Internet]. 2012 [cited 2016 Dec 10];15(2):309-22. Available from: http://www.scielo.br/ pdf/rlpf/v15n2/07.pdf

14. Severo AKS, L'Abbate S, Campos RTO. A supervisão clínico-institucional como dispositivo de mudanças na gestão do trabalho em saúde mental. Interface Comum Saúde Educ [Internet]. 2014 [cited 2016 Nov 15];18(50):545-56. Available from: http://www.scielo.br/pdf/icse/v18n50/18075762-icse-1807-576220130520.pdf

15. Fernandes JD, Sadigursky D, Silva RMO, Amorim AB, Teixeira GAS, Araújo MCF. Ensino da enfermagem psiquiátrica/saúde mental: sua interface com a reforma psiquiátrica e diretrizes curriculares nacionais. Rev Esc Enferm USP [Internet]. 2009 [cited 2016 Dec 10];43(4):962-8. Available from: http://www.scielo.br/pdf/reeusp/v43n4/a31v43n4.pdf

16. Fernandes JD, Rebouças LC. Uma década de Diretrizes Curriculares Nacionais para a Graduação em Enfermagem: avanços e desafios. Rev Bras Enferm [Internet]. 2013 [cited 2016 Dec 20];66(esp):95-101. Available from: http://www.scielo.br/pdf/reben/v66nspe/v66nspea13.pdf

17. Martinho J, Pires R, Carvalho JC, Pimenta G. Formação e desenvolvimento de competências de estudantes de enfermagem em contexto de ensino clínico em saúde mental e psiquiatria. Rev Port Enferm Saúde Mental [Internet]. 2014 [cited 2017 Jan 10];1:97-102. Available from: http://www.scielo.mec.pt/pdf/rpesm/nspe1/nspe1a16.pdf

18. Mariano ALS. A aprendizagem da docência no início da carreira: qual política? Quais problemas? Rev Exitus. 2012;2(01):79-94.

19. Aragão MN, Soares IG. (Trans)formando e ousando o método de ensino em enfermagem no cuidado à saúde mental. Rev Port Enferm Saúde Mental [Internet]. 2014 [cited 2017 Jan 10];12:59-64. Available from: http://www.scielo.mec.pt/pdf/rpesm/n12/n12a08.pdf

20. Esperidião E, Barbosa J, Silva N, Munari D. A saúde mental do aluno de Enfermagem: Revisão integrativa da literatura. SMAD, Rev Eletrônica Saúde Mental Álcool Drog [Internet]. 2013;9(3):14453. Available from: http://www.redalyc.org/articulo.oa?id=80331797008 


\section{NOTES}

\section{CONTRIBUTION OF AUTHORITY}

Study design: Rodrigues J.

Data analysis and interpretation: Rodrigues J, Lazzari DD.

Writing and / or critical review of content: Rodrigues J, Lazzari DD, Martini JG, Testoni AK.

Review and final approval of the final version: Rodrigues J, Lazzari DD, Martini JG.

\section{ETHICS COMMITTEE IN RESEARCH}

Approved by the Research Ethics Committee of the Federal University of Santa Catarina, opinion no. 724.391, Presentation Certificate for Ethical Assessment $n^{\circ}$ 33241314.2.0000.0121.

\section{CONFLICT OF INTEREST}

There is no conflict of interest.

\section{HISTORICAL}

Received: February 20, 2017.

Approved: September 26, 2017.

\section{CORRESPONDENCE AUTHOR}

Jeferson Rodrigues

jeferson.rodrigues@ufsc.br 